Article

\title{
A Multidecadal Analysis of Föhn Winds over Larsen C Ice Shelf from a Combination of Observations and Modeling
}

\author{
Jasper M. Wiesenekker*, Peter Kuipers Munneke, Michiel R. van den Broeke ${ }^{\mathbb{D}}$ and \\ C. J. P. Paul Smeets \\ Institute for Marine and Atmospheric Research, Utrecht University, 3508 TA Utrecht, The Netherlands; \\ p.kuipersmunneke@uu.nl (P.K.M.); m.r.vandenbroeke@uu.nl (M.R.v.d.B.); c.j.p.p.smeets@uu.nl (C.J.P.P.S.) \\ * Correspondence: jmwiesenekker@gmail.com (J.M.W.); Tel.: +31-30-253-3275
}

Received: 3 April 2018; Accepted: 2 May 2018; Published: 5 May 2018

\begin{abstract}
The southward progression of ice shelf collapse in the Antarctic Peninsula is partially attributed to a strengthening of the circumpolar westerlies and the associated increase in föhn conditions over its eastern ice shelves. We used observations from an automatic weather station at Cabinet Inlet on the northern Larsen C ice shelf between 25 November 2014 and 31 December 2016 to describe föhn dynamics. Observed föhn frequency was compared to the latest version of the regional climate model RACMO2.3p2, run over the Antarctic Peninsula at 5.5-km horizontal resolution. A föhn identification scheme based on observed wind conditions was employed to check for model biases in föhn representation. Seasonal variation in total föhn event duration was resolved with sufficient skill. The analysis was extended to the model period (1979-2016) to obtain a multidecadal perspective of föhn occurrence over Larsen C ice shelf. Föhn occurrence at Cabinet Inlet strongly correlates with near-surface air temperature, and both are found to relate strongly to the location and strength of the Amundsen Sea Low. Furthermore, we demonstrated that föhn occurrence over Larsen C ice shelf shows high variability in space and time.
\end{abstract}

Keywords: Föhn; Antarctic Peninsula; Larsen ice shelf; multidecadal analysis; automatic weather station; regional climate model

\section{Introduction}

Multiple ice shelves fringing the Antarctic Peninsula (AP) east coast have recently collapsed in quick succession, namely Prince Gustav (January 1995), Larsen A (January 1995) and Larsen B (February 2002) [1-3]. Since ice shelves buttress grounded glaciers upstream [4], their disintegration has led to acceleration of tributary glaciers and subsequent sea-level rise [1,5-7]. The collapse of these ice shelves was preceded by the formation of meltwater ponds [2,8]. Surface melt and ensuing meltwater ponding increase the hydrostatic pressure in ice shelf fractures and may thereby have reduced ice shelf stability [9].

Ice shelf retreat and collapse is likely a response to near-surface air temperatures along the AP having increased between the 1950s and 2000s at higher rates than the global average $[10,11]$. The warming trend is partially explained by changes in the atmospheric circulation around the AP [12]. The dominant mode of circulation in the Southern Hemisphere (SH), the SH Annular Mode (SAM), has shifted towards a positive phase in recent decades [13]. As a result, changes in the meridional pressure gradient caused a strengthening of the circumpolar vortex, inducing more frequent and stronger westerlies over the AP [12]. A positive correlation between the SAM index and 
near-surface temperature exists across the peninsula, suggesting that westerly flow and AP warming are related [14-16].

With enhanced westerly flow, the winds impinging on the AP are more likely to pass over the orographic barrier, potentially inducing a föhn response on the east coast $[12,17]$. When such a linear flow regime exists, the föhn effect encompasses drying of air on its ascent and warming as it descends the leeward slopes of the mountains on top of the already warmer maritime air. In a few hours, near-surface temperatures over the eastern ice shelves can rise by more than $20^{\circ} \mathrm{C}$, when föhn winds replace cold air masses that commonly occupy these ice shelves $[18,19]$.

Recent work on föhn in the AP has quantified the impact of specific föhn events on the surface energy budget, linking it to patterns of melt over Larsen ice shelves during föhn conditions [20-23]. The dynamics and impact of föhn during single events or one melt season have been well described, yet long-term observations and analyses remain scarce. The first multidecadal study on AP föhn used data from the Argentine Matienzo station, located between former Larsen A and Larsen B embayments [19]. After quantifying föhn frequency and duration, a strong relationship with near-surface temperature was found [19]. Analyses on spatial distribution suggested that föhn frequency, duration and strength have a very localized signature over the Larsen $C$ ice shelf (LCIS) $[24,25]$. Most föhn occurs near the foot of the AP mountain range and in the north of the ice shelf, gradually decreasing in frequency southeastward [24,25].

In this paper, we study the dynamics of föhn in the AP using a combination of observations and regional climate modeling. First, we examine data of an Automatic Weather Station (AWS) located in Cabinet Inlet, in the northwest section of LCIS. These data are compared to output of the polar version of the regional climate model RACMO2, the output of which enables us to discuss variability of föhn on annual and decadal time scales (1979-2016). Finally, we demonstrate how föhn in different parts of the AP is associated with different large-scale circulation patterns.

\section{Methods}

\subsection{Automatic Weather Station}

We used observational data from an automatic weather stations (AWS) located in Cabinet Inlet (CI). AWS18 was erected in the framework of project MIDAS (Impact of Melt on ice shelf Dynamics and Stability), led by Swansea and Aberystwyth Universities. The AWS is jointly operated by the Institute for Marine and Atmospheric Research of Utrecht University (UU/IMAU) and the British Antarctic Survey (BAS). It is located on the floating ice shelf at $66^{\circ} 24^{\prime} \mathrm{S}, 63^{\circ} 22^{\prime} \mathrm{W}$, approximately $70 \mathrm{~m}$ above sea level (Figure 1). This ice-covered embayment is located on the northern part of Foyn Coast, situated between Cole and Churchill Peninsulas. The AWS is situated on floating ice close to the grounding line of LCIS, roughly $25 \mathrm{~km}$ downstream of the AP mountain range. The peaks of these mountains reach altitudes of around $2000 \mathrm{~m}$ and feature steep slopes. A gap is located in the mountain ridge near CI, which acts as a conduit for air to be channeled towards the LCIS [24].

Along with GPS location, AWS18 measures the following near-surface meteorological variables: air temperature, horizontal wind speed and direction, relative humidity, air pressure, snow surface height, and incoming/outgoing shortwave and longwave radiative fluxes. The sampling interval for wind speed and direction is $4 \mathrm{~s}$; for temperature, humidity and radiation, it is $60 \mathrm{~s}$; and $30 \mathrm{~min}$ for pressure, snow height and GPS coordinates. All data are averaged into $30 \mathrm{~min}$ intervals. In this study, we used data from 25 November 2014 18:00 UTC to 31 December 2016 23:30 UTC. The temperature sensor was unaspirated and therefore known to suffer from radiation errors during calm and sunny days, hence a correction was applied based on wind speed and net shortwave radiation [26,27]. For comparison with RACMO2 data, the temperature and wind speed were corrected to elevations of 2 and $10 \mathrm{~m}$, respectively, using a surface energy balance model and surface layer similarity theory [20]. Near-surface meteorological variables presented in this paper represent instantaneous values. 


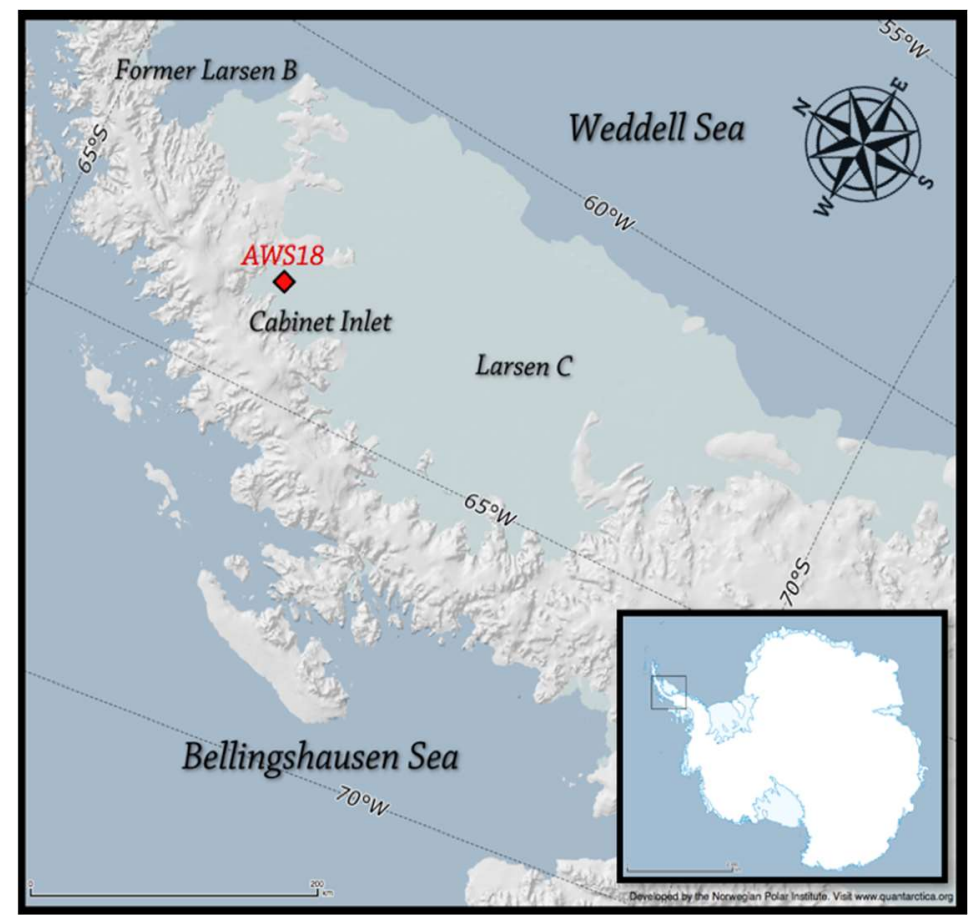

Figure 1. Map of the Antarctic Peninsula. The red diamond depicts location of AWS18.

\subsection{Regional Climate Model RACMO2}

We used output at high horizontal resolution $(5.5 \mathrm{~km} \times 5.5 \mathrm{~km})$ model run over the AP with the most recent version of the regional atmospheric climate model RACMO2.3p2, hereafter referred to as RACMO2 [28]. It uses 40 hybrid vertical levels, 10 of which are located in the lowest $1 \mathrm{~km}$, and the lowest level is situated less than $10 \mathrm{~m}$ above the surface. The model uses the dynamical core of the High Resolution Limited Area Model (HIRLAM) [29] and the physics package of the European Centre for Medium-range Weather Forecasts (ECMWF) Integrated Forecast System [28], cycle CY33r1. It is specifically adapted for use over large ice sheets [30] and uses a multilayer snow model [31], a prognostic surface albedo scheme based amongst others on snow grain size [32] and a routine which accounts for drifting snow [33]. It assumes hydrostatic equilibrium, which is found to provide realistic results when compared with surface and upper-air observations [34]. The latest version of the model is equipped with tuned cloud scheme parameters, allowing for increased cloud moisture retention, and modified snow properties, which reduce drifting snow sublimation and increase surface snowmelt compared to the previous version [28].

ERA-Interim (1979-2016) reanalysis data [35] were used to force the lateral atmospheric boundaries and to prescribe sea ice fraction and sea surface temperatures [28]. The surface topography was obtained by a combination of digital elevation models [36,37]. Model output is available at a 3-hourly resolution from 1 January 1979 0:00 UTC to 31 December 2016 21:00 UTC. RACMO2 near-surface meteorological values represent instantaneous values, allowing for a direct comparison with AWS18 data.

\subsection{Föhn Identification}

Föhn is an umbrella term for warm and dry winds at the leeward side of mountains. A more precise, generally valid definition does not exist, likely because of the local character of the phenomenon. We applied a simple föhn detection algorithm to AWS18 data and RACMO2 output based on wind speed and direction, adapted to best represent föhn at CI. Our three criteria to distinguish föhn events are: 
1. Wind direction at the surface must be southwesterly $\left(225^{\circ}\right)$ to northerly $\left(0^{\circ}\right)$.

2. Wind speed at the AWS location surface must exceed $4 \mathrm{~m} \mathrm{~s}^{-1}$.

3. A föhn event must last at least $3 \mathrm{~h}$ (two consecutive data points must meet Criteria 1 and 2).

The wind direction criterion selects periods when air originates from the mountains. The second criterion represents the observation that föhn events over inlets of the Larsen $C$ ice shelf are associated with high wind speeds [24]. By rejecting weak and/or short-lived events, we filter out local thermal wind phenomena such as katabatic winds. In addition, a sensitivity analysis revealed that a wind speed threshold of $4 \mathrm{~m} \mathrm{~s}^{-1}$ leads to the highest overlap of föhn events detected by both observations and model, i.e., for $83 \%$ of the föhn data points identified in the AWS record, föhn conditions are simulated by RACMO2 at the same time. Placing the threshold at $2 \mathrm{~m} \mathrm{~s}^{-1}$ and $3 \mathrm{~m} \mathrm{~s}^{-1}$ resulted in a $65 \%$ and $75 \%$ match, respectively.

The three criteria were applied to select föhn events during the overlapping period (25 November 2014-31 December 2016) in the AWS data and the RACMO2 model output at the AWS location. In RACMO2, this yielded 1002 three-hourly data points that matched the criteria. We qualitatively checked these RACMO2 föhn data points by assessing surface relative humidity (expected to be lower than the climatological average of $\sim 70 \%$ ), surface air temperature (expected to be higher compared to upwind locations), and wind direction at $500 \mathrm{hPa}$ (is expected to be southwesterly to northerly). We found that, over the period 25 November 2014-31 December 2016, only 12 out of the 1002 föhn data points $(1.2 \%)$ were falsely positive, which suggests that the currently chosen föhn detection criteria are sufficiently accurate.

To spatially expand our assessment of föhn, we applied the same three criteria to two other locations near CI. A location north of CI was selected in Evans Inlet $\left(65^{\circ} 05^{\prime} \mathrm{S}, 61^{\circ} 29^{\prime} \mathrm{W}\right)$, in the former Larsen B embayment near Hektoria, Green and Evans Glaciers. Mobil Oil Inlet (68 $32^{\prime}$ S, $65^{\circ} 05^{\prime}$ W) was selected as a location south of CI. For this inlet, the wind direction criterion was adjusted by tilting the range slightly counterclockwise $\left(202.5^{\circ}\right.$ to $\left.337.5^{\circ}\right)$, to account for the direction of the mountain crest near the inlet. These locations were selected because of their comparable proximity to the AP mountain range. Additionally, a mountain gap exists near these inlets (similar to CI), allowing westerly flow to be channeled towards the inlet. This channeling of air promotes high wind speeds [24].

\subsection{Climate Index}

To link interannual variability to synoptic scale processes, we compared averaged monthly föhn event duration (in hours per month) to indices of the Amundsen Sea Low (ASL) [38]. The ASL is a climatological low-pressure system situated in the Amundsen and Bellingshausen Seas to the west of the AP. We used monthly averages of core pressure and core latitudinal position, because these affect storm intensity and path over the AP, respectively [39].

\section{Results and Discussion}

First, the dynamics of föhn in CI as recorded by AWS18 are presented and interpreted in Section 3.1, followed by a comparison with RACMO2 in Section 3.2. In Sections 3.3 and 3.4 the analysis of föhn winds in the model is extended both in time (1979-2016) and in space.

\subsection{Observational Föhn Characteristics}

Application of the three föhn criteria (Section 2.3) to AWS18 data between 25 November 2014 and 31 December 2016 yielded a total of 130 individual föhn events, totaling approximately 107 days of föhn (14.0\% of the time). Roughly $80 \%$ of these events lasted no longer than a day, and less than $5 \%$ lasted longer than $48 \mathrm{~h}$ (black lines in Figure 2). In terms of wind speed at the AWS site, $50 \%$ of the föhn events were associated with wind speeds under $8 \mathrm{~m} \mathrm{~s}^{-1}$, whereas only $5 \%$ of the föhn winds exceeded $16 \mathrm{~m} \mathrm{~s}^{-1}$. The seasonal distribution of total monthly föhn duration reveals a highly variable pattern, averaging $103 \mathrm{~h}$ per month with a standard deviation of $84 \mathrm{~h}$ per month (Figure 3). Averaging over all 
föhn events resulted in a $2 \mathrm{~m}$ air temperature anomaly of $+8.9^{\circ} \mathrm{C}$ and skin temperature anomaly of $+8.5^{\circ} \mathrm{C}$ (Table 1). Relative humidity during föhn was $25 \%$ lower on average, as a result of increased saturation vapor pressure.
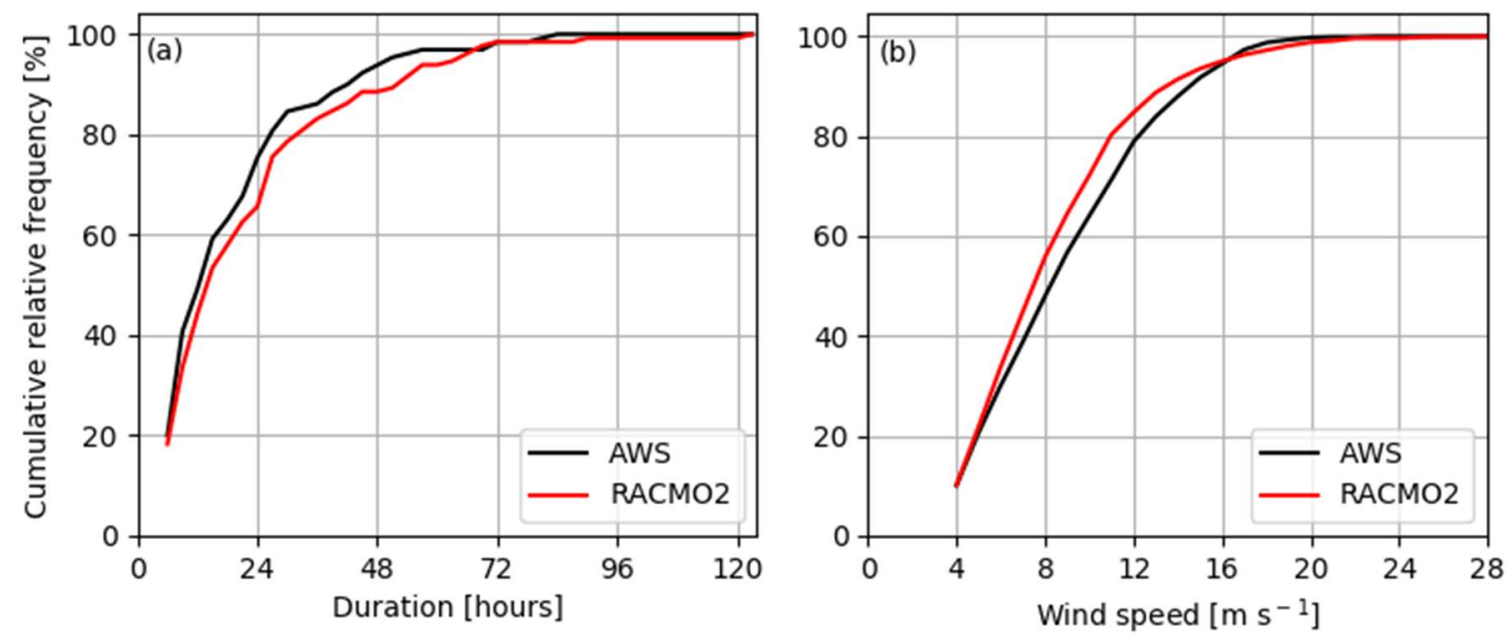

Figure 2. Cumulative relative frequency of: (a) föhn duration; and (b) föhn wind speed.

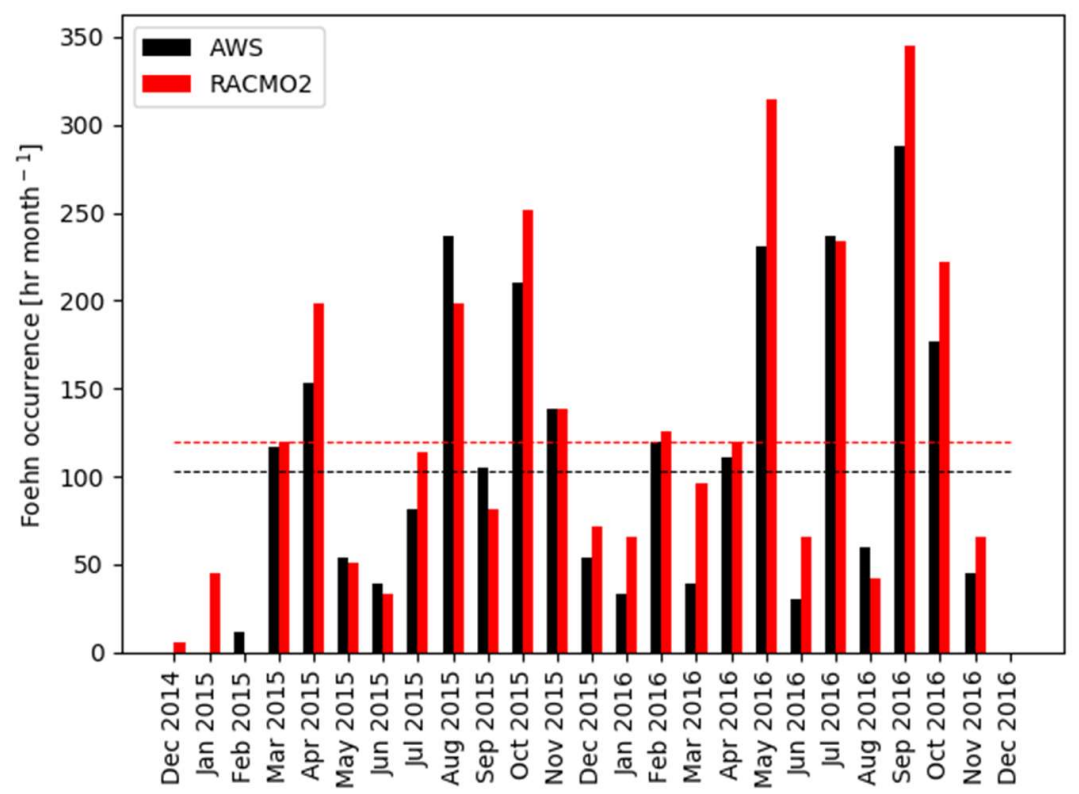

Figure 3. Hours of föhn per month. Dashed line denotes the average over the December 2014-December 2016 period.

The effects of föhn on near-surface conditions are further demonstrated by a case study of a well-developed, early-autumn föhn event. On 23 March 2015, a low-pressure system reached the northern AP and proceeded to pass over the peninsula. This resulted in outspoken föhn conditions at $\mathrm{CI}$ in the observational data. Air temperatures at $2 \mathrm{~m}$ were nearly $20{ }^{\circ} \mathrm{C}$ higher during föhn conditions than a day earlier (Figure 4a). Skin temperature reached the melting point during most of the föhn event (Figure $4 \mathrm{~b}$ ). Relatively high wind speeds (up to $10 \mathrm{~m} \mathrm{~s}^{-1}$, Figure $4 \mathrm{c}$ ) from a predominantly northwesterly direction (Figure 4d) further characterized this event. The AWS captured the variable nature of the wind very well, as with each slight turning of the wind towards northeasterly, wind speed was greatly reduced and föhn conditions were briefly interrupted. Lastly, relative humidity decreased by approximately $40 \%$ during the event (Figure $4 \mathrm{e}$ ). 
Table 1. Three-hour averaged near-surface meteorological variables over the entire period (All) and during föhn conditions (Föhn).

\begin{tabular}{cccccc}
\hline Parameters & \multirow{2}{*}{ Unit } & \multicolumn{2}{c}{ All } & \multicolumn{2}{c}{ Föhn } \\
& & AWS & RACMO2 & AWS & RACMO2 \\
\hline Air temperature $(2 \mathrm{~m})$ & ${ }^{\circ} \mathrm{C}$ & -11.3 & -10.4 & -2.4 & -2.7 \\
Skin temperature & ${ }^{\circ} \mathrm{C}$ & -13.2 & -13.7 & -4.7 & -6.9 \\
Relative humidity $(2 \mathrm{~m})$ & $\%$ & 89.1 & 74.4 & 63.7 & 57.4 \\
Wind speed $(10 \mathrm{~m})$ & $\mathrm{m} \mathrm{s}^{-1}$ & 3.6 & 3.5 & 8.7 & 8.6 \\
Wind direction & $\circ$ & 279 & 268 & 300 & 307 \\
\hline
\end{tabular}
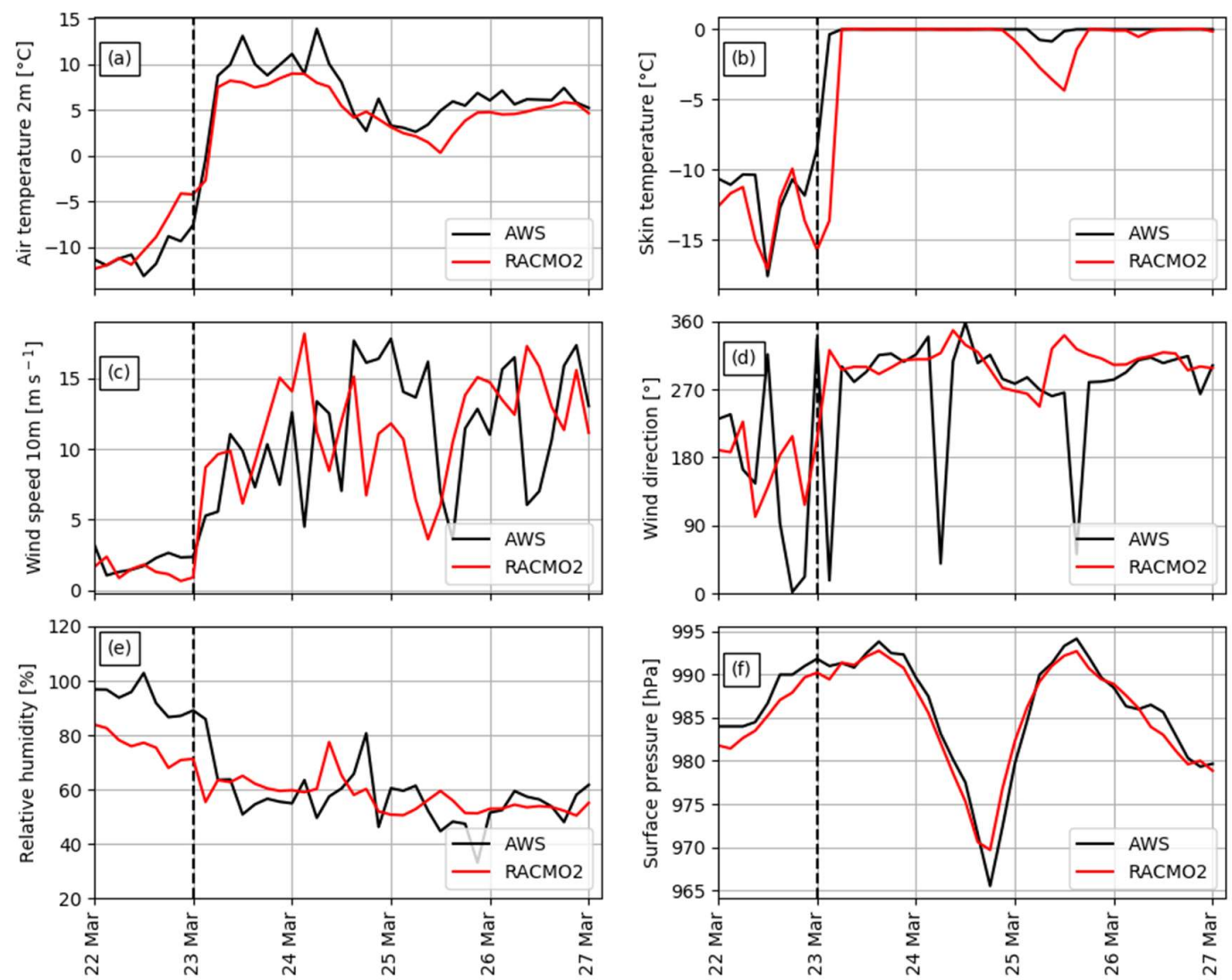

Figure 4. Time evolution of: (a) $2 \mathrm{~m}$ air temperature; (b) skin temperature; (c) $10 \mathrm{~m}$ wind speed; (d) wind direction; (e) relative humidity; and (f) surface pressure from 22 to 27 March 2015. The black dashed line denotes the transition from non-föhn to föhn conditions, as used in the text.

\subsection{RACMO2 Model Evaluation}

The RACMO2 grid cell containing the AWS18 coordinates is selected for comparison of near-surface meteorological variables (Table 2) and föhn event frequency. The period of overlap between AWS observations and RACMO2 is approximately 767 days. Averaged over this entire period, there generally is a good correspondence between model and observations for $2 \mathrm{~m}$ air temperature and specific humidity. However, modeled relative humidity shows a negative bias of $14 \%$ and a significantly poorer correlation. This bias is particularly present during conditions with a very low wind speed, i.e., non-föhn conditions. The observed relative humidity from an AWS being naturally ventilated may be affected by riming causing a positive bias. Surface pressure is modeled with a high degree of skill $\left(r^{2}=0.980\right)$, which indicates that mesoscale and synoptic weather systems influencing the AWS location are resolved adequately. Wind speed at $10 \mathrm{~m}$ is only resolved with moderate skill: the variable nature of wind as observed by the AWS is smoothed out in the model, likely because of both 
limited horizontal and vertical model resolution. The surface skin temperature, which governs melt, is well represented $\left(r^{2}=0.851\right)$ in the model, although it shows an average cold bias of $0.5^{\circ} \mathrm{C}$.

Table 2. Comparison of near-surface meteorological variables in RACMO2 and AWS over the period 25 November 2014 18:00 UTC to 31 December 2016 21:00 UTC.

\begin{tabular}{cccccc}
\hline Parameters & Unit & ME & RMSE & $r$ & $r^{2}$ \\
\hline Air temperature $(2 \mathrm{~m})$ & ${ }^{\circ} \mathrm{C}$ & 0.9 & 4.2 & 0.925 & 0.856 \\
Specific humidity $(2 \mathrm{~m})$ & $\mathrm{g} \mathrm{kg}^{-1}$ & 0.0 & 0.4 & 0.931 & 0.843 \\
Relative humidity $(2 \mathrm{~m})$ & $\%$ & -13.6 & 20.9 & 0.520 & 0.270 \\
Skin temperature & ${ }^{\circ} \mathrm{C}$ & -0.5 & 4.2 & 0.923 & 0.851 \\
Surface pressure & $\mathrm{hPa}$ & -1.5 & 2.1 & 0.990 & 0.980 \\
Wind speed & $\mathrm{m} \mathrm{s}^{-1}$ & -0.1 & 2.4 & 0.766 & 0.587 \\
\hline
\end{tabular}

RACMO2 recorded 131 föhn events spanning a total of approximately 125 days ( $16.3 \%$ of the time) during the AWS18 observational period. The föhn events that were recorded by RACMO2 lasted longer than those observed at the AWS (Figure 2a) but had lower wind speeds (Figure 2b). At this resolution, RACMO2 clearly does not capture high-frequency variability in wind speed and wind direction (Figure $4 \mathrm{c}, \mathrm{d}$ ), which probably explains the greater duration of föhn events compared to the AWS: high variability of wind interrupts the föhn in the AWS data, thereby dividing these cases into several smaller events. The seasonal distribution of events, as expressed by monthly frequencies, is represented very well in the model $\left(r^{2}=0.909\right.$, Figure 3$)$. However, the averaged $120 \mathrm{~h}$ of föhn per month (standard deviation of $94 \mathrm{~h} \mathrm{month}{ }^{-1}$ ) is notably higher than the AWS average, due to the increased longevity of events in the model.

When the full period is considered, RACMO2 is biased towards higher air temperatures and lower relative humidity (Table 1). Averaged wind speed and direction correspond well with observations. The average differences between observations and model decrease during föhn conditions. Both model and observations show that averaged $2 \mathrm{~m}$ air temperature increased and relative humidity decreased during föhn, which is a föhn characteristic. A wind speed increase and a northerly shift in averaged wind direction is also attributable to föhn, but an objective comparison is impaired by the imposed föhn criteria through these parameters.

The model skin temperature bias is larger during föhn, which results in underestimated snow melt duration (Figure $4 \mathrm{~b}$ ). The case study reveals that RACMO2 modeled air temperature is too low during föhn (Figure 4a), which through the sensible heat flux affects the skin temperature. The observed variable nature of the wind, with brief excursions towards a northeasterly direction during which relative humidity increased and air temperature and wind speed decreased, is not simulated by RACMO2. In addition, the negative relative humidity bias of the model is clearly observable during both föhn and non-föhn conditions (Figure 4e). Surface pressure evolution during the föhn event is resolved with excellent skill (Figure 4f).

\subsection{Temporal Variability of Föhn Occurrence at CI}

Bearing in mind the strengths and weaknesses of the model demonstrated in the model evaluation (Section 3.2), we extend the föhn event identification scheme in RACMO2 over the full hindcast period (1979-2016). In this way, we are able to obtain a multi-decadal and spatial perspective on föhn event occurrence and impact on the climate of CI.

Total föhn event occurrence has a high interannual variability, but a clear seasonal pattern emerges when averaging total monthly föhn duration over the 38-year period (Figure 5). Most föhn occurs in winter and spring, peaking in September. The smallest total of föhn duration is recorded in summer, at less than half the total duration of winter föhn events. Synoptic scale atmospheric flow variability around the Antarctic Peninsula is sensitive to the position and strength of the Amundsen Sea Low (ASL) [19]. Our analysis confirms this, as a high correlation exists between total monthly föhn duration 
at CI and monthly averages of ASL core pressure $(r=-0.81)$ and latitude of the ASL center $(r=0.92)$. Lower core pressure and a more poleward position in winter coincides with the peak in föhn event occurrence, as storms are more intense and their tracks are directed over the AP.

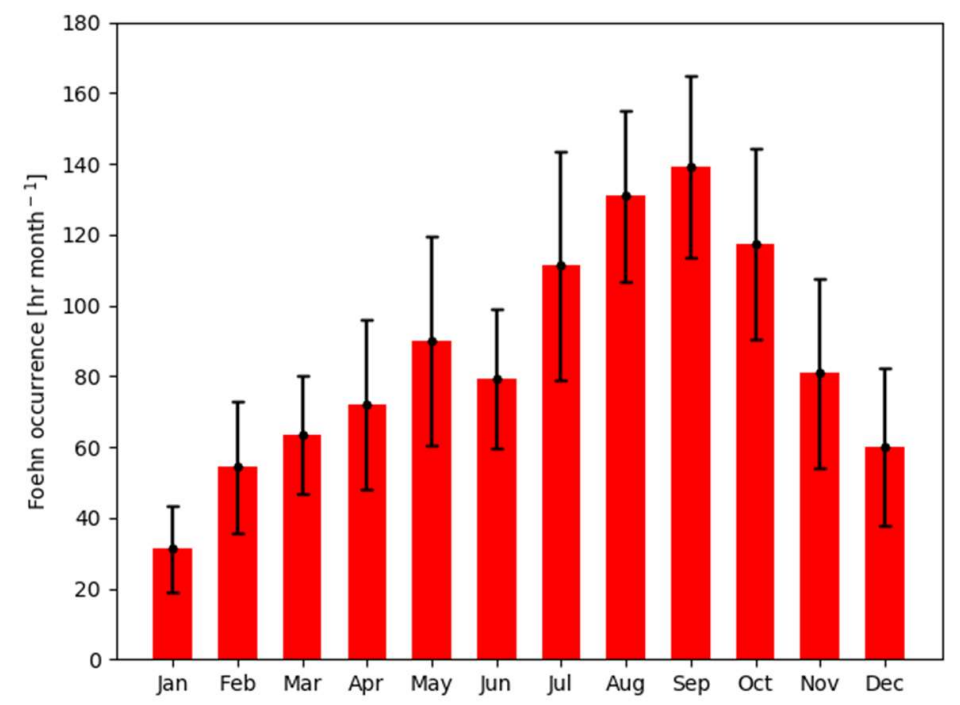

Figure 5. Modeled monthly averaged hours of föhn per month over the period 1979-2016. Error bars depict one standard deviation.

Summer föhn conditions have seen an uninterrupted increase at CI from 1980 to 2004 (Figure 6a), after which a decline is observed up to 2016. In spring, föhn hours per month at CI have decreased since 1990 (Figure 6d) and variability remains relatively low throughout the period, compared to other seasons. This variability is highest in autumn and winter.
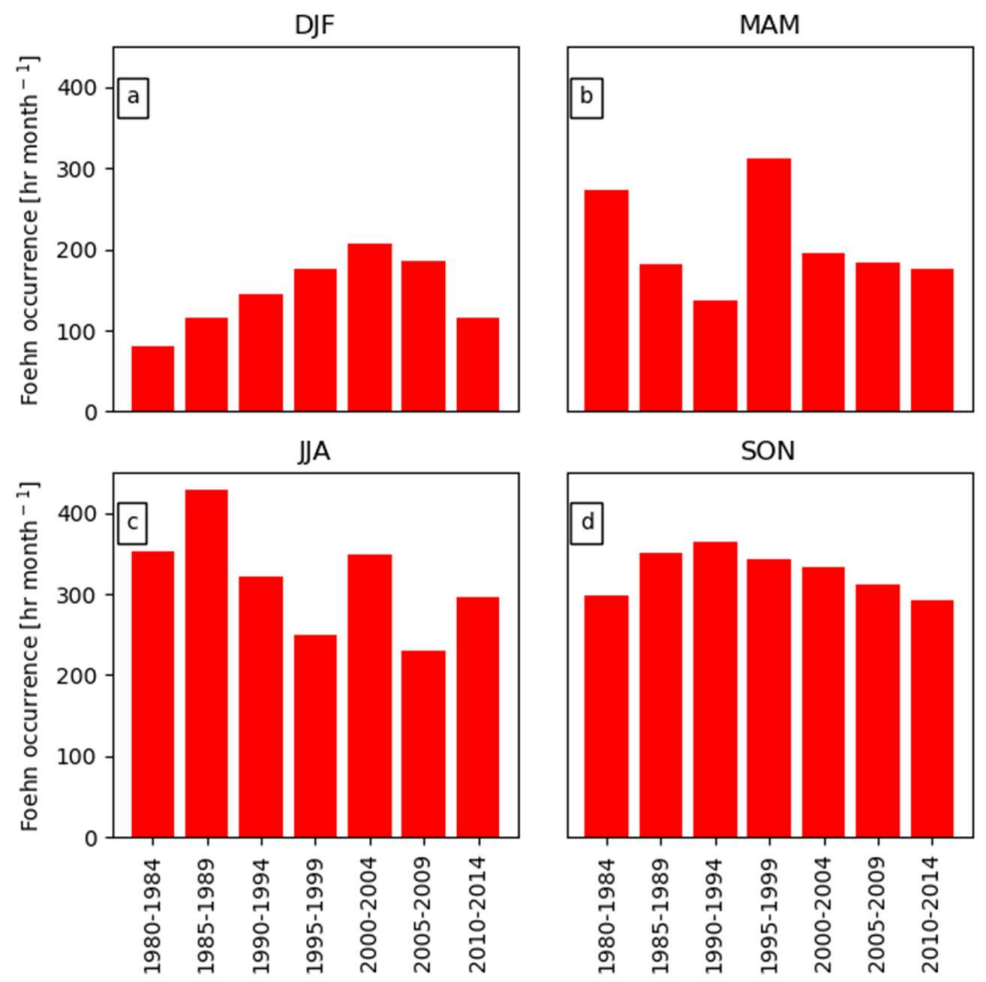

Figure 6. Modeled five-year average of hours of föhn per month for: (a) summer (DJF); (b) autumn (MAM); (c) winter (JJA); and (d) spring (SON). 
The strong interannual variability is also clearly visible in the fluctuation of days of föhn per year (red lines in Figure 7). The yearly averaged surface air temperature and total föhn duration at CI are very strongly correlated ( $r=0.903$ ) at CI (Figure 7). This demonstrates that föhn events determine to a large extent the temperature and its variability at CI. In addition, in other Antarctic locations prone to föhn, such a strong relation between föhn occurrence and air temperature was noted [39]. The spatial extent of this impact is discussed in the next section.

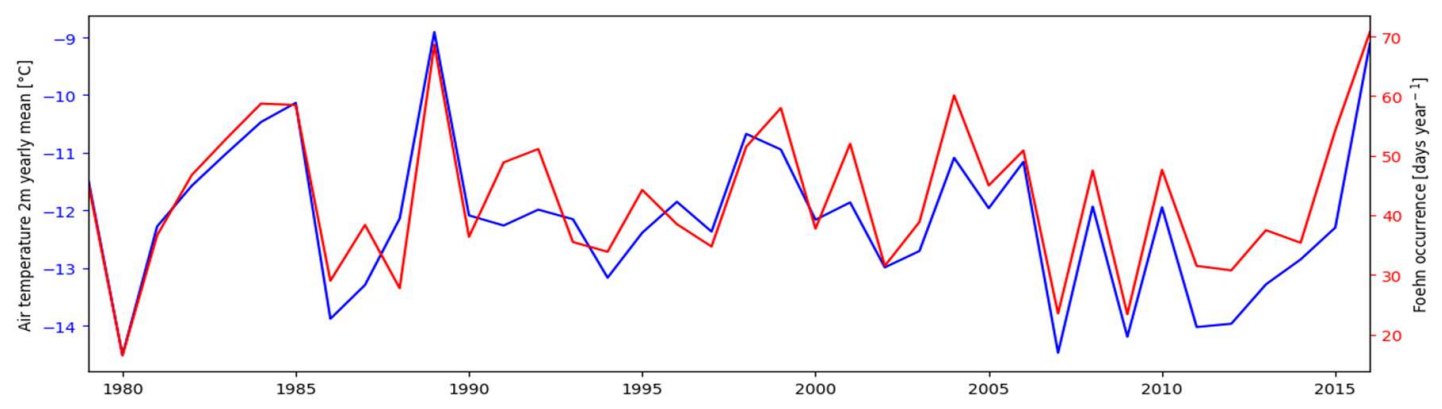

Figure 7. Annual-averaged $2 \mathrm{~m}$ air temperature (blue) and total annual föhn duration (red).

\subsection{Spatial Impact of Föhn in the AP}

RACMO2 output enables us to display the Larsen C ice shelf-wide 1979-2016 average $2 \mathrm{~m}$ temperature anomaly during föhn conditions at CI (Figure 8). When föhn occurs at CI from late autumn to early spring, modeled $2 \mathrm{~m}$ air temperatures are up to $12{ }^{\circ} \mathrm{C}$ higher than average on the LCIS. In such cases, skin temperature can reach the melting point even in mid-winter. In May, July and August, the entire LCIS is affected by above-average temperatures, whereas, in the other months, the warming is concentrated in the region near the foot of the AP mountain range, gradually diminishing towards the east. The highest warming is modeled near other inlets, indicating that föhn occurs simultaneously at CI and other inlets. The temperature anomaly is smallest during the summer months, when the surface-based temperature inversion over the LCIS becomes small in response to a positive surface radiation balance [34] and wind speed is lower than in winter.
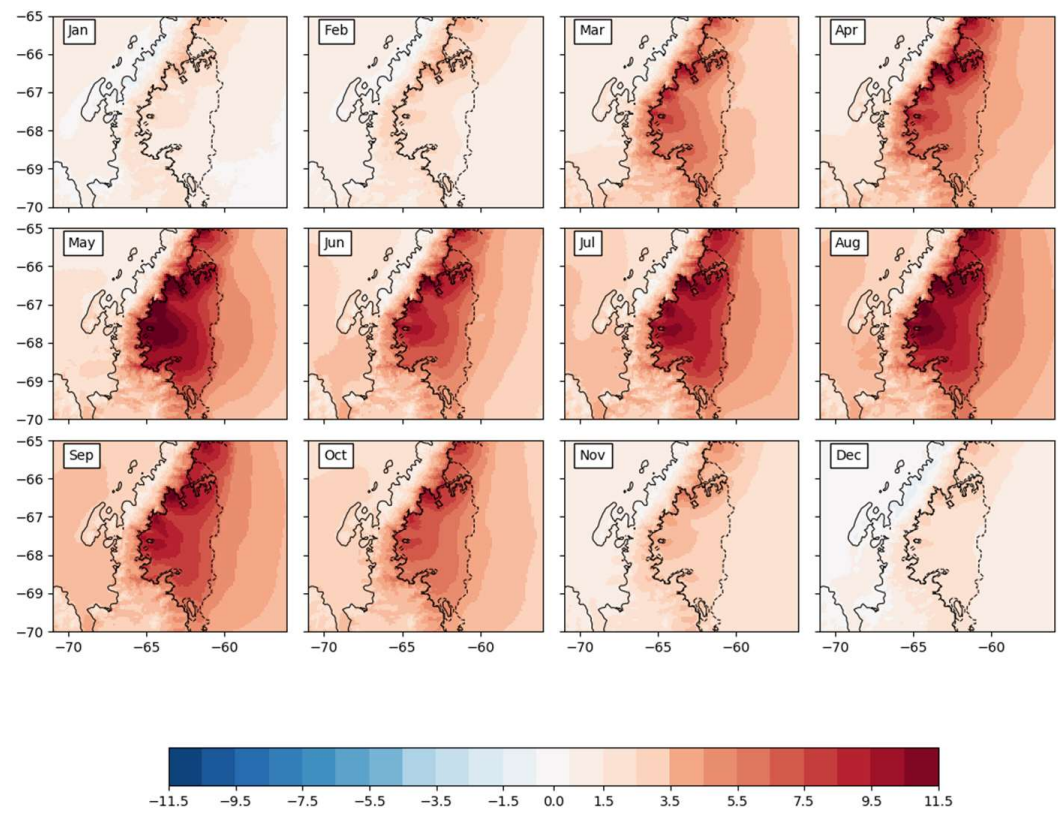

Figure 8. Two-meter air temperature anomaly $\left({ }^{\circ} \mathrm{C}\right)$ during föhn occurring at Cabinet Inlet for each month from 1980 to 2016. 
To further our insight into the spatial variability of föhn impact on the climate of LCIS, the föhn identification scheme was also applied to a location in Evans Inlet (EI), in the Larsen B embayment, and to Mobil Oil Inlet (MOI), located on the southern LCIS. The number of recorded föhn events is comparable for each inlet, however there is a clear difference in spatial representation (Figure 9). When föhn conditions are present over EI, temperature anomalies and wind speeds are highest at EI, whereas those parameters are more weakly influenced over LCIS to the south (Figure 9a). Similarly, föhn at MOI leads to minor temperature and wind speed anomalies at EI (Figure 9c). Clearly, föhn at $\mathrm{CI}$ is the best predictor for temperature anomalies over the entire LCIS. Furthermore, when föhn is occurring at CI, föhn conditions are also present at EI and föhn jets are easily distinguished over the inlets south of CI. Presumably, this is because upwind wind direction (northwesterly) is favorable for föhn at both CI and EI.
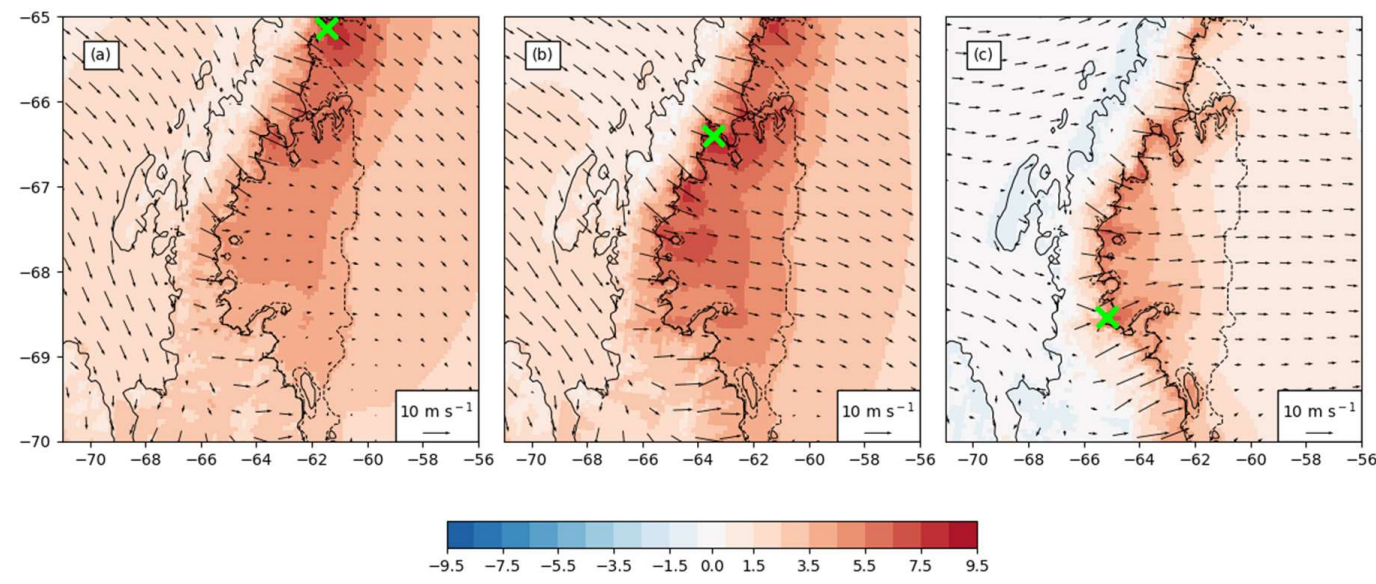

Figure 9. Two-meter air temperature anomaly $\left({ }^{\circ} \mathrm{C}\right)$ and averaged wind vectors during föhn occurring over the period 1980 to 2016 at: (a) Evans Inlet; (b) Cabinet Inlet; and (c) Mobil Oil Inlet. Locations are indicated by a lime-colored " $x$ ".

\section{Summary and Conclusions}

We have assessed föhn characteristics as recorded by AWS18, located in CI on Larsen C ice shelf in the Antarctic Peninsula. Local föhn events were identified based on three criteria, namely wind direction, wind speed and duration. Previous studies revealed that föhn at Larsen $C$ ice shelf is governed by upwind conditions at higher altitude [22,23]. Manual checking of wind direction at $500 \mathrm{hPa}$ showed a positive föhn identification error of only $1.2 \%$, likely caused by the stringent minimum wind speed criterion of $4 \mathrm{~m} \mathrm{~s}^{-1}$. The disadvantage of such a high minimum near-surface wind speed threshold is that weaker föhn events are not selected. The benefit is that local wind phenomena such as katabatic winds are filtered out. Other observation-based studies assessing föhn onset and cessation imposed criteria based on rapid changes in near-surface relative humidity, air temperature and wind speed $[19,25,40]$. We acknowledge that föhn is mainly a thermodynamic phenomenon, so the use of relative humidity and temperature is indeed a more natural one. However, the significant model bias in relative humidity precluded using an additional humidity criterion in our analysis. We found $99.7 \%$ of our selected modeled föhn events were among the $50 \%$ driest of the entire period and $96.5 \%$ of the observed föhn events, which demonstrates the capacity of our scheme to capture the characteristic humidity signature of föhn. Although we have successfully demonstrated the performance of the relatively simple wind speed criterion for locations close to the foot of the AP mountain range where föhn-induced wind speeds are strongest [24], one should be cautious in using it for other locations where föhn may occur.

We assessed RACMO2 model performance in representing CI föhn climate by comparing the modeled seasonality in total monthly föhn event duration with observational data from AWS18. Most of the near-surface meteorological variables correspond well, as they display strong correlations. 
Discrepancies between model and observations can likely be attributed to the fact that the AWS measures purely locally, whereas the model represents a $5.5 \times 5.5 \mathrm{~km}^{2}$ grid cell. The magnitude of coefficients of determination for near-surface meteorological variables closely match those found in another study [34].

During the observational period (November 2014-December 2016), we recognized a strong temporal variability in föhn occurrence in both model and observations, with some months exhibiting many föhn events, whilst in some months none were recorded. Most föhn occurrences were in winter and spring, while the fewest were found in summer. The total exposure of the LCIS to föhn conditions over the observational period is $14 \%$ of the time. Despite their notable difference in föhn detection algorithm, both peak föhn frequency and exposure time are consistent with existing literature $[19,23,25]$.

The climate of Larsen $C$ ice shelf is on average characterized by cold air advection from the south, resulting in a strong surface-based temperature inversion being present especially in winter [34]. This temperature inversion is removed under föhn conditions, which in addition to the common warming from föhn events leads to a sharp increase in (near-)surface air temperature. As a result, annual averages of near-surface air temperature at CI are highly correlated with föhn occurrence. Locations north of CI demonstrate a similar correlation [19]. This demonstrates that föhn events have a large impact on regional climate and variability. Furthermore, our study showed strong correlations between actual core pressure and latitude of the Amundsen Sea Low and föhn occurrence, indicating an important role of the ASL on Larsen C climate. Increases in föhn frequency coincide with a strengthening and poleward movement of the Amundsen Sea Low (ASL), bringing more storm tracks over the Antarctic Peninsula [39,41].

The AP has experienced a warming trend in the period 1979 to 1999 and a cooling trend from 2000 to 2014, in line with the trends in föhn events and bringing recent AP temperature time series within natural variability [42]. The most recent years in our study, 2015 and 2016, saw an increase in föhn events and temperatures at CI, after a period of relatively few föhn events and associated lower temperatures from 2000 onwards. The causes of this development are worth investigating in future studies, as its persistence could lead to warming and enhanced melt over Larsen C ice shelf.

Our spatial analysis based on RACMO2 output shows that the occurrence of föhn at CI is a good predictor for positive temperature anomalies over the entire Larsen $\mathrm{C}$ ice shelf, in contrast to locations in inlets to the north and south. It therefore seems worthwhile to maintain this AWS into the future, as a valuable benchmark for Larsen $C$ climate variability and change.

Author Contributions: J.M.W. and P.K.M. conceived the ideas for this study. J.M.W. performed the scientific analysis. C.J.P.P.S. prepared the automatic weather station data, and P.K.M. post-processed these data. All authors contributed to writing and editing of the paper.

Funding: This research was funded by a Netherlands Earth System Science Centre (NESSC) grant to M.R.v.d.B. The automatic weather station is partly funded by MIDAS (Impact of Melt on Ice Shelf Dynamics and Stability), a NERC award granted to Swansea and Aberystwyth Universities under number NE/L006707.

Acknowledgments: J.M.W. and P.K.M. acknowledge funding from the Netherlands Earth System Science Centre (NESSC). We thank Willem Jan van de Berg, Melchior van Wessem (IMAU) and the Royal Netherlands Meteorological Institute (KNMI) for RACMO2 support. J.M.W. appreciates support from Leo Kroon and Bert Holtslag (Wageningen University and Research). Finally, we thank the British Antarctic Survey personnel for servicing of the AWS. The AWS18 dataset is publicly accessible and can be found online [43]. RACMO2 data are available from the authors without conditions.

Conflicts of Interest: The authors declare no conflict of interest.

\section{References}

1. Rott, H.; Skvarca, P.; Nagler, T. Rapid collapse of northern Larsen ice shelf, Antarctica. Science 1996, 271, 788-792. [CrossRef]

2. Scambos, T.A.; Hulbe, C.; Fahnestock, M.; Bohlander, J. The link between climate warming and break-up of ice shelves in the Antarctic Peninsula. J. Glaciol. 2000, 46, 516-530. [CrossRef] 
3. Cook, A.J.; Vaughan, D.G. Overview of areal changes of the ice shelves on the Antarctic Peninsula over the past 50 years. Cryosphere 2010, 4, 77-98. [CrossRef]

4. Dupont, T.K.; Alley, R.B. Assessment of the importance of ice-shelf buttressing to ice-sheet flow. Geophys. Res. Lett. 2005, 32, L022024. [CrossRef]

5. Scambos, T.A.; Bohlander, J.A.; Shuman, C.U.; Skvarca, P. Glacier acceleration and thinning after ice shelf collapse in the Larsen B embayment, Antarctica. Geophys. Res. Lett. 2004, 31. [CrossRef]

6. Rignot, E.; Casassa, G.; Gogineni, P.; Krabill, W.; Rivera, A.U.; Thomas, R. Accelerated ice discharge from the Antarctic Peninsula following the collapse of Larsen B ice shelf. Geophys. Res. Lett. 2004, 31. [CrossRef]

7. Wuite, J.; Rott, H.; Hetzenecker, M.; Floricioiu, D.; De Rydt, J.; Gudmundsson, G.H.; Kern, M.; Thomas, N.; Michael, K. Evolution of surface velocities and ice discharge of Larsen B outlet glaciers from 1995 to 2013. Cryosphere 2015, 9, 957-969. [CrossRef]

8. Van den Broeke, M. Strong surface melting preceded collapse of Antarctic Peninsula ice shelf. Geophys. Res. Lett. 2005, 32. [CrossRef]

9. Van der Veen, C.J. Fracture propagation as means of rapidly transferring surface meltwater to the base of glaciers. Geophys. Res. Lett. 2007, 34. [CrossRef]

10. Vaughan, D.G.; Marshall, G.J.; Connolley, W.M.; Parkinson, C.; Mulvaney, R.; Hodgson, D.A.; Turner, J.; King, J.C.; Pudsey, C.J.; Turner, J. Recent rapid regional climate warming on the Antarctic Peninsula. Clim. Chang. 2003, 60, 243-274. [CrossRef]

11. Turner, J.; Colwell, S.R.; Marshall, G.J.; Lachlan-Cope, T.A.; Carleton, A.M.; Jones, P.D.; Lagun, V.; Reid, P.A.; Iagovkina, S. Antarctic climate change during the last 50 years. Int. J. Clim. 2005, 25, 279-294. [CrossRef]

12. Marshall, G.J.; Orr, A.; van Lipzig, N.P.; King, J.C. The impact of a changing Southern Hemisphere Annular Mode on Antarctic Peninsula summer temperatures. J. Clim. 2006, 19, 5388-5404. [CrossRef]

13. Marshall, G.J. Trends in the Southern Annular Mode from observations and reanalyses. J. Clim. 2003, 16, 4134-4143. [CrossRef]

14. Thompson, D.W.; Solomon, S. Interpretation of recent Southern Hemisphere climate change. Science 2002, 296, 895-899. [CrossRef] [PubMed]

15. Kwok, R.; Comiso, J.C. Spatial patterns of variability in Antarctic surface temperature: Connections to the Southern Hemisphere Annular Mode and the Southern Oscillation. Geophys. Res. Lett. 2002, 29, L015415. [CrossRef]

16. Van den Broeke, M.R.; van Lipzig, N.P. Changes in Antarctic temperature, wind and precipitation in response to the Antarctic Oscillation. Ann. Glaciol. 2004, 39, 119-126. [CrossRef]

17. Orr, A.; Cresswell, D.; Marshall, G.J.; Hunt, J.C.; Sommeria, J.; Wang, C.G.; Light, M. A ‘low-level' explanation for the recent large warming trend over the western Antarctic Peninsula involving blocked winds and changes in zonal circulation. Geophys. Res. Lett. 2004, 31. [CrossRef]

18. Orr, A.; Marshall, G.J.; Hunt, J.C.; Sommeria, J.; Wang, C.G.; van Lipzig, N.P.; King, J.C.; Cresswell, D.; King, J.C. Characteristics of summer airflow over the Antarctic Peninsula in response to recent strengthening of westerly circumpolar winds. J. Atmos. Sci. 2008, 65, 1396-1413. [CrossRef]

19. Cape, M.R.; Vernet, M.; Skvarca, P.; Marinsek, S.; Scambos, T.; Domack, E. Foehn winds link climate-driven warming to ice shelf evolution in Antarctica. J. Geophys. Res. Atmos. 2015, 120. [CrossRef]

20. Kuipers Munneke, P.; van den Broeke, M.R.; King, J.C.; Gray, T.; Reijmer, C.H. Near-surface climate and surface energy budget of Larsen C ice shelf, Antarctic Peninsula. Cryosphere 2012, 6. [CrossRef]

21. Grosvenor, D.P.; King, J.C.; Choularton, T.W.; Lachlan-Cope, T. Downslope fohn winds over the Antarctic Peninsula and their effect on the Larsen ice shelves. Atmos. Chem. Phys. 2014, 14, 9481-9509. [CrossRef]

22. Elvidge, A.D.; Renfrew, I.A.; King, J.C.; Orr, A.; Lachlan-Cope, T.A. Foehn warming distributions in nonlinear and linear flow regimes: A focus on the Antarctic Peninsula. Q. J. R. Meteorol. Soc. 2016, 142, 618-631. [CrossRef]

23. King, J.C.; Kirchgaessner, A.; Bevan, S.; Elvidge, A.D.; Kuipers Munneke, P.; Luckman, A.; van den Broeke, M.R. The impact of föhn winds on surface energy balance during the 2010-11 melt season over Larsen C Ice Shelf, Antarctica. J. Geophys. Res. Atmos. 2017, 122. [CrossRef]

24. Elvidge, A.D.; Renfrew, I.A.; King, J.C.; Orr, A.; Lachlan-Cope, T.A.; Weeks, M.; Gray, S.L. Foehn jets over the Larsen C ice shelf, Antarctica. Q. J. R. Meteorol. Soc. 2015, 141, 698-713. [CrossRef]

25. Turton, J.V.; Kirchgaessner, A.; Ross, A.N.; King, J.C. The spatial distribution and temporal variability of föhn winds over the Larsen C Ice Shelf, Antarctica. Q. J. R. Meteorol. Soc. 2018, accepted. [CrossRef] 
26. Smeets, C.J.P.P. Assessing unaspirated temperature measurements using a thermocouple and a physically based model. Mass Budg. Arct. Glaciers 2006, 99, 99-101.

27. Smeets, C.J.P.P.; Kuipers Munneke, P.; van den Broeke, M.R.; Boot, W.; Oerlemans, J.; Snellen, H.; Reijmer, C.H.; van de Wal, R.S.W. The K-transect in west Greenland: Twenty-three years of automatic weather station data. Arct Antarct. Alp. Res. 2018, in press.

28. Van Wessem, J.M.; van de Berg, W.J.; Noël, B.P.; van Meijgaard, E.; Birnbaum, G.; Jakobs, C.L.; Medley, B.; Reijmer, C.H.; van Tricht, K.; Trusel, L.D.; et al. Modelling the climate and surface mass balance of polar ice sheets using RACMO2, part 2: Antarctica (1979-2016). Cryosph. Discuss. 2017, in press. [CrossRef]

29. Undén, P.; Rontu, L.; Jarvinen, H.; Lynch, P.; Calvo Sánchez, F.J.; Cats, G.; Jones, C.; Lenderlink, G.; Mcdonald, A.; McGrath, R.; et al. HIRLAM-5 Scientific Documentation; Hirlam: Norrköping, Sweden, 2002.

30. Reijmer, C.H.; van Meijgaard, E.; van den Broeke, M.R. Evaluation of temperature and wind over Antarctica in a Regional Atmospheric Climate Model using 1 year of automatic weather station data and upper air observations. J. Geophys. Res: Atmos. 2005, 110. [CrossRef]

31. Ettema, J.; van den Broeke, M.R.; van Meijgaard, E.; van de Berg, W.J. Climate of the Greenland ice sheet using a high-resolution climate model-Part 2: Near-surface climate and energy balance. Cryosphere 2010, 4, 529-544. [CrossRef]

32. Kuipers Munneke, P.; van den Broeke, M.R.; Lenaerts, J.T.M.; Flanner, M.G.; Gardner, A.S.; van de Berg, W.J. A new albedo parameterization for use in climate models over the Antarctic ice sheet. J. Geophys. Res. Atmos. 2011, 116. [CrossRef]

33. Lenaerts, J.T.M.; van den Broeke, M.R.; Déry, S.J.; van Meijgaard, E.; van de Berg, W.J.; Palm, S.P.; Sanz Rodrigo, J. Modeling drifting snow in Antarctica with a regional climate model: 1 . Methods and model evaluation. J. Geophys. Res. Atmos. 2012, 117. [CrossRef]

34. Van Wessem, J.M.; Reijmer, C.H.; van de Berg, W.J.; van den Broeke, M.R.; Cook, A.J.; van Ulft, L.H.; van Meijgaard, E. Temperature and wind climate of the antarctic Peninsula as Simulated by a high-resolution regional atmospheric climate model. J. Clim. 2015, 28, 7306-7326. [CrossRef]

35. Dee, D.P.; Uppala, S.M.; Simmons, A.J.; Berrisford, P.; Poli, P.; Kobayashi, S.; Bechtold, P.; Beljaars, A.C.M.; van de Berg, L.; Bidlot, J.; et al. The ERA-Interim reanalysis: Configuration and performance of the data assimilation system. Q. J. R. Meteorol. Soc. 2011, 137, 553-597. [CrossRef]

36. Bamber, J.L.; Gomez-Dans, J.L.; Griggs, J.A. A new $1 \mathrm{~km}$ digital elevation model of the Antarctic derived from combined satellite radar and laser data-Part 1: Data and methods. Cryosphere 2009, 3, 101-111. [CrossRef]

37. Cook, A.J.; Murray, T.; Luckman, A.; Vaughan, D.G.; Barrand, N.E. A new 100-m Digital Elevation Model of the Antarctic Peninsula derived from ASTER Global DEM: Methods and accuracy assessment. Earth Syst. Sci. Data 2012, 4, 129-142. [CrossRef]

38. Amundsen Sea Low (ASL) index. Available online: https://legacy.bas.ac.uk/data/absl/ (accessed on 16 November 2017).

39. Hosking, J.S.; Orr, A.; Bracegirdle, T.J.; Turner, J. Future circulation changes off West Antarctica: Sensitivity of the Amundsen Sea Low to projected anthropogenic forcing. Geophys. Res. Lett. 2016, 43, 367-376. [CrossRef]

40. Speirs, J.C.; McGowan, H.A.; Steinhoff, D.F.; Bromwich, D.H. Regional climate variability driven by foehn winds in the McMurdo Dry Valleys, Antarctica. Int. J. Clim. 2013, 33, 945-958. [CrossRef]

41. Turner, J.; Chenoli, S.N.; Marshall, G.; Phillips, T.; Orr, A. Strong wind events in the Antarctic. J. Geophys. Res. Atmos. 2009, 114. [CrossRef]

42. Turner, J.; Lu, H.; White, I.; King, J.C.; Phillips, T.; Hosking, J.S.; Bracegirdle, T.J.; Marshall, G.J.; Mulvaney, R.; Deb, P. Absence of 21st century warming on Antarctic Peninsula consistent with natural variability. Nature 2016, 535, 411-415. [CrossRef] [PubMed]

43. Dataset from iWS 18 in Cabinet Inlet, Larsen C Ice Shelf, Antarctica, 2014-2017. Available online: http: / / doi.org/10.5285/05c9124b-7119-4d99-8e17-ab754eb3f51c (accessed on 13 October 2017).

(C) 2018 by the authors. Licensee MDPI, Basel, Switzerland. This article is an open access article distributed under the terms and conditions of the Creative Commons Attribution (CC BY) license (http:/ / creativecommons.org/licenses/by/4.0/). 